\title{
Transformasi Digital Majalah Hai Dalam Upaya Mempertahankan Eksistensi Brand
}

\author{
Emma Rachmawati Aliudin ${ }^{1}$., Melisa Arisanty ${ }^{2}$ \\ ${ }^{1}$ Program Studi Ilmu Komunikasi, Universitas Pembangunan Jaya \\ emma.aliudin@upj.ac.id \\ ${ }^{2}$ Program Studi Ilmu Komunikasi, Universitas Pembangunan Jaya \\ melisa.arisanty@upj.ac.id
}

\begin{abstract}
Hai teen magazine has stopped publishing since June 2017. The magazine that was published since 1997 has officially transformed into digital media format. This change further strengthens the assumption that the print media business continues to decline. The role of print media has been replaced by digital media. Digital transformation begins with a multiplatform strategy in which Hai magazine content is presented in various platforms (convergence). This strategy is carried out to provide a variety of content choices in order to respond to the challenges of changing media consumption among teenagers. This research was conducted to obtain a comprehensive understanding of the digital transformation process of Hai magazine in order to maintain the existence of its brand. This qualitative research uses a case study approach. The results of the study are expected to contribute as a foundation in developing the media industry and show the trend of digital transformation in the media today.
\end{abstract}

Keywords : Digital Transformation, print media, brand existance

\begin{abstract}
Abstrak : Industri media cetak di Indonesia semakin memasuki fase kepunahan. Dihentikannya majalah remaja Hai, salah satu majalah remaja populer di Indonesia, semakin memperkuat asumsi bahwa industri media cetak di Indonesia kian tergeser oleh kelompok media massa yang berbasis digital. Sejak Juni 2017, media yang sudah beroperasi dari tahun 1977 tersebut secara resmi berpindah total ke platform digital. Majalah Hai merupakan majalah bersegmentasi remaja yang diterbitkan oleh Kompas Gramedia. Majalah ini memiliki peran penting dalam sejarah media cetak di Tanah Air dan terbukti berpengaruh besar dalam menginspirasi kaum muda Indonesia. Transformasi atau perpindahan dari platform cetak ke platform digital tidak dilakukan secara drastis namun melalui konsep multiplatform yang menggabungkan beberapa platform media (konvergensi). Upaya ini dilakukan untuk memberikan pilihan konten dan medium yang beragam dalam rangka menjawab tantangan perubahan pola konsumsi media dan trend penggunaan media di kalangan remaja saat ini. Dengan adanya gambaran fenomena tersebut perlu dilakukan penelitian kualitatif dengan strategi penelitian studi kasus untuk menganalisis secara mendalam latar belakang proses transformasi digital suatu media cetak dalam upaya mempertahankan eksistensi brand-nya. Dengan demikian, hasil penelitian ini akan berkontribusi sebagai landasan pengambilan kebijakan dalam mengembangkan industri media dan menunjukkan trend transformasi digital pada industri media saat ini.
\end{abstract}

Kata Kunci : Transformasi Digital, Media Cetak, Eksistensi Brand 


\section{PENDAHULUAN}

...semua industri tengah bertarung menghadapi cara-cara baru dengan strategi baru. Strategi baru itu dikembangkan dengan metode 'The Future" yang dibawa ke bisnis hari ini, sementara pelaku-pelaku usaha lama masih membawa "the past" ke hari ini. Mana bisa mereka bertahan? (Priyantono Rudito, Ph.D)

Kalangan industri kini tengah menghadapi kecemasan dan tantangan perubahan yang mendasar, salah satunya akibat perkembangan teknologi informasi yang begitu pesat dan seolah tak terbendung. Perubahan yang mengubah hampir seluruh tatanan kehidupan manusia.

"Hampir semua industri tengah bertarung menghadapi lawanlawan baru yang masuk tanpa mengikuti pola yang selama ini kita kenal. Mereka bahkan tak terlihat, tapi tahu-tahu menjadi sedemikian besar. Bahkan sangat-sangat besar. Mereka langsung masuk ke rumah-rumah konsumen, dari pintu ke pintu, secara online, melalui smartphone." (Kasali, 2017:xi)

Industri majalah, satu yang mengalami tekanan hebat. Sejak kehadiran internet yang kemudian mengubah lansekap industri media menjadi media tradisional dan media baru, media cetak termasuk majalah sudah diprediksi akan mengalami kepunahan. Diskusi ini sesungguhnya sudah berlangsung sejak awal kemunculan teknologi itu sendiri. Hadirnya teknologi internet dan pesatnya perkembangan teknologi komunikasi serta informasi yang melahirkan media baru berbasis digital telah mengubah perilaku masyarakat dalam mengonsumsi media massa. Konsumen secara signifikan berpindah dari penggunaan media massa konvensional ke media baru. Media cetak kehilangan pembacanya secara drastis, terutama pembaca muda (Baran and Davis, 2010: 278). Prediksi bahwa industri majalah akan mati, makin menjadi kenyataan dengan berhenti beroperasinya sejumlah majalah berskala internasional maupun nasional.

Data Nielsen menyebutkan televisi masih menjadi media utama bagi masyarakat Indonesia. Hal ini tercermin dari survei Nielsen Consumer Media View (CMV) yang menunjukkan bahwa penetrasi televisi pada tahun 2017 mencapai 96 persen. Di urutan kedua media luar ruang dengan penetrasi 53 persen, internet 44 persen, dan radio 37 persen.

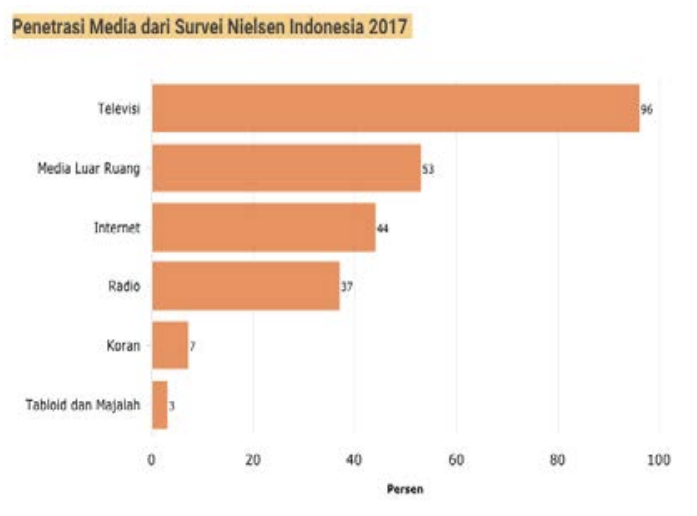

Gambar 1. Penetrasi Media dan Survei Nielen Indonesia

Keberadaan internet sebagai media dengan tingkat penetrasi cukup tinggi mengindikasikan bahwa masyarakat Indonesia semakin gemar mengakses berbagai konten melalui media digital. Padahal dalam lima tahun lalu (2012), penestrasi internet baru mencapai 26 persen. Data ini menunjukkan media digital mengalami perkembangan yang cukup tinggi.

Perkembangan media digital tersebut mempengaruhi eksistensi media konvensional. Media konvensional, menghadapi tekanan yang serius dari media baru. Google kini adalah raja media, melampaui televisi, jaringan kabel, jaringan surat kabar dan majalah, sebagai kendaraan nomor satu untuk iklan. Selain itu hadirnya media sosial juga berpotensi 
mendominasi lingkungan online (Straubhaar, 2012:275).

Gejala ini sebenarnya sudah banyak diantisipasi oleh para pengelola majalah. Roger Fiddler, dalam bukunya yang terkenal Mediamorphorsis, Understanding New Media memperkenalkan konsep mediamorphosis. Istilah mediamorphosis didefinisikan sebagai proses transformasi media komunikasi yang biasanya disebabkan oleh interaksi yang kompleks dari kebutuhan yang mendesak, tekanan persaingan bisnis, politik dan sosial, serta inovasi teknologi. Menurutnya, media harus berubah dalam merespons kemunculan medium baru. Pilihan lainnya adalah mati. (Fiddler, 1997: 23). Lebih lanjut ia menyebutkan bahwa prinsip utama mediamorphosis terdiri dari 3 konsep yaitu coevolution (koevolusi), convergence (konvergensi) dan complexity (kompleksitas).

Konsep konvergensi umumnya diterapkan oleh perusahaan media berbasis cetak dalam beradaptasi dengan perubahan teknologi yang mengarah ke digitalisasi. Paradigma konvergensi mengasumsikan media lama dan media baru tetap akan hidup bersama dan berinteraksi dengan kecenderungan media lama yang harus beradaptasi dengan kemajuan teknologi. (Jenkins, 2006:14). Artinya, konvergensi secara teori dipercaya bisa menjadi sebuah solusi untuk mempertahankan eksistensi media tradisional dalam menghadapi tekanan media baru.

Namun praktik di lapangan berkata lain. Langkah konvergensi yang dilakukan oleh sejumlah perusahaan media tidak mampu mencegah laju perpindahan audiens dari media konvensional (cetak) ke media baru (digital). Sehingga konvergensi yang dilakukan pada akhirnya bisa dikatakan hanya menjadi semacam transisi dari media cetak untuk berpindah total ke media baru. Sejumlah brand majalah akhirnya menyerah dan menghentikan penerbitan versi cetaknya. Sebagai cara untuk mempertahankan eksistensi brand, sejumlah pengelola majalah kemudian memutuskan untuk melakukan transformasi secara total ke dalam format digital.

Salah satu yang sering disebut sebagai contoh sukses transformasi digital di bidang majalah adalah The New York Times. Kesuksesan The New York Times setidaknya didukung oleh dua langkah. Pertama, mereka menggunakan data pelanggan lama mereka untuk masuk ke dunia digital. Kedua, perusahaan itu juga tak sungkan menciptakan produk-produk baru dalam konteks digital. Aplikasi smartphone bernama Cooking dan Cross Word adalah contoh kesuksesan itu. Dua aplikasi itu sukses membawa konsumen berlangganan The New York Times versi digital. (tirto.id,2018)

Di Indonesia, contoh tranformasi digital bisa dilihat pada majalah remaja Hai, sebuah brand media dalam kelompok Gramedia Majalah, bagian dari PT Kompas Gramedia yang merupakan publishing company terbesar di Indonesia. Dilansir dari website resmi Hai di laman hai.grid.id, mulai Juni 2017, versi cetak majalah Hai dihentikan. Selanjutnya Hai hanya muncul dalam platform digital. Menurut keterangan yang disampaikan pada laman tersebut, perubahan strategi publikasi ini dimaksudkan agar semakin memudahkan para pembaca majalah HAI yang kebanyakan berasal dari generasi millenial. Perpindahan cetak ke digital ini juga dijanjikan akan membuat konsep konten HAI semakin seru dan inovatif. Pada edisi perpisahannya Hai muncul dengan cover tanpa gambar dan hanya dipenuhi headline berupa tulisan We Need More Space dilengkapi tagar \#needmorespace. Kabar berhentinya Hai cukup menarik perhatian masyarakat dan kalangan media, karena brand Hai di industri media sangat kuat. Netizen bahkan membuat tagar \#RIPHAI. Romantisme Majalah Hai masih cukup kuat terasa hingga kini, terutama bagi generasi paruh baya -tahun 1970-an hingga akhir 1990-an- yang pernah lama merasakan memegang versi cetak Majalah 
Hai di tangan mereka. (kumparan.com, 2018)

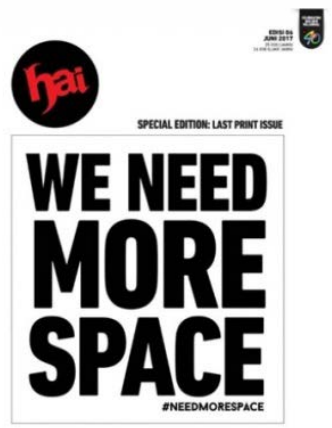

Gambar 2. Cover cetak edisi terakhir Hai Sumber: hai.grid.id

Menarik mengikuti perjalanan Majalah Hai dalam menghadapi era media baru. Di awal kehadiran internet, media yang telah berusia lebih dari 40 tahun ini sempat diprediksi oleh sejumlah kalangan akan tumbang lebih dulu karena bermain di segmen remaja. Seperti diketahui, segmen remaja merupakan generasi digital native yang lahir di era digital yang akrab dengan teknologi digital dan paling cepat meninggalkan tradisi membaca media cetak. Sebagai proses adaptasi dengan lingkungan media baru, Hai kemudian merambah platform digital dan muncul dalam konsep publikasi multimedia, hingga akhirnya memutuskan untuk menghentikan versi cetaknya dan bertranformasi total dari media berbasis cetak ke media digital sejak tahun 2017. Proses transformasi digital dalam mempertahankan eksistensi brand, menjadi fokus dalam penelitian ini.

\section{Rumusan Masalah}

Penelitian ini mencoba menjawab pertanyaan 'Bagaimana Majalah Hai melakukan transformasi digital dalam upaya mempertahankan eksistensi brand?'

\section{Tujuan Penelitian}

Tujuan praktis: Mengetahui perkembangan industri media massa khususnya bagaimana media tradisional beradaptasi dengan lingkungan media baru.

1.3.2. Tujuan akademis: Mengetahui proses Majalah Hai melakukan transformasi digital dalam upaya mempertahankan eksistensi brand

\section{KAJIAN PUSTAKA \\ Transformasi Digital}

Dalam buku The Digital Transformation Playbook (2016), David L Rogers mengatakan bahwa transformasi digital bukan soal teknologi, tetapi lebih kepada strategi dan cara pandang baru. Menurut Rogers, transformasi di era digital menuntut perusahaan memperbarui pemikiran strategisnya jauh melebihi infrastruktur IT.

Transformasi digital menurut pandangan Rogers meliputi 5 wilayah strategi yaitu customer, competition, data, innovation dan value. Penjelasannya adalah sebagai berikut (Rogers, David L, 2016, p.16-19):

1. Customers atau pelanggan, pada teori tradisional kastemer dipandang sebagai kumpulan orang yang merupakan target market dan target persuasi untuk membeli sesuatu. Di era digital kastemer dipandang sebagai kumpulan orang yang secara dinamis terhubung dan berinteraksi dengan cara-cara tertentu yang mengubah hubungan mereka dengan produsen dan hubungan dengan sesama kastemer.

2. Competition atau kompetisi, menurut pandangan tradisional pesaing bisnis adalah kompetitor yang mirip dan berasal dari industri yang sama. Di era digital, kompetitor justru bisa muncul dari arah yang tak terduga, yang sangat berbeda dan bisa saja dari industri di luar bidang yang digeluti, namun memberikan tawaran yang menarik kepada customer kita. Sehingga batas industri menjadi sangat cair.

3. Data, bidang ini terkait dengan persoalan bagaimana perusahaan 
memproduksi, mengelola dan memanfaatkan informasi. Dalam pendekatan tradisional, data dihasilkan melalui berbagai pengukuran yang terencana dan terukur, misalnya melalui inventori data dan riset terhadap konsumen. Data ini yang kemudian digunakan untuk melakukan evaluasi, membuat prediksi dan mengambil keputusan bisnis. Kontras dengan pendekatan di era digital, di mana perusahaan bisa mendapatkan dan mengolah data dari pembicaraan, interaksi atau proses di luar internal perusahaan. Misalnya melalui media sosial, perangkat mobile atau alat analisis lainnya.

4. Innovation atau inovasi yaitu proses di mana gagasan-gagasan baru dibangun, diuji dan diperkenalkan kepada pasar oleh perusahaan. Secara tradisional inovasi biasanya dilakukan menggunakan produk yang sudah jadi. Uji pasar tidak dilakukan karena sulit dan mahal. Sehingga keberhasilan sebuah inovasi biasanya ditentukan oleh analisis dan intuisi para manajer perusahaan. Di era digital, sebuah inovasi bisa dipelajari sejak praproduksi hingga pascaproduksi sehingga perusahaan bisa mengembangkan produk yang tepat sasaran dengan proses yang lebih efisien.

5. Value atau nilai, ini merupakan domain final transformasi digital, yaitu bagaimana value yang dimiliki oleh perusahaan disampaikan kepada kastemer. Secara tradisional, value proposition perusahaan dilihat sebagai proses yang berlangsung konstan. Misalnya dimulai dengan pengembangan produk, penyegaran kampanye pemasaran atau perbaikan layanan. Namun pada prinsipnya, value perusahaan dipandang sebagai sesuatu yang konstan dan didefinisikan oleh perusahaan. Sedangkan pada era digital, perusahaan harus melakukan evolusi pengembangan bisnis dan memanfaatkan seluruh teknologi yang ada untuk memperluas dan mengembangkan daya saing perusahaan di mata kastemer. Ketimbang hanya menunggu dan beradaptasi menunggu hidup dan mati, perusahaan harus fokus dalam menciptakan peluang-peluang baru, melepaskan investasi-investasi yang merugikan dan menjadi pionir perubahan.

Bisa dikatakan, transformasi digital adalah keputusan yang bersifat strategis. Keputusan-keputusan yang bersifat strategis (Strategic decisions) dibuat dengan mempertimbangkan berbagai faktor dan selalu terkait dengan: Arah (direction) jangka panjang dari sebuah organisasi; Cakupan (scope) aktivitas organisasi; Upaya memperoleh keunggulan (advantage) organisasi dari pesaingnya; Identifikasi perubahanperubahan dalam lingkungan bisnis (business environment); Membangun sumber daya dan kompetensi (capability); Nilai-nilai dan harapan (values \& expectation) pemangku kepentingan (Johnson, Scholes, Whittington, 2005: 43).

Dengan kata lain, strategi harus menjawab persoalan-persoalan yang berkaitan dengan: Posisi yang hendak dicapai perusahaan dalam jangka panjang; Di mana perusahaan berkompetisi dan apa jenis aktivitas apa yang dilakukan di sana; Bagaimana perusahaan bisa memiliki kinerja lebih baik dibanding para pesaingnya; Apa saja sumber daya (kompetensi, aset, finansial, fasilitas, hubungan dengan stake holders, dll) yang dimiliki perusahaan untuk bisa memenangkan persaingan; Bagaimana faktor lingkungan internal dan eksternal memengaruhi kemampuan perusahaan 
dalam berkompetisi?; Bagaimana nilainilai dan harapan-harapan pemangku kepentingan?

Menurut Jones \& Hill (2013:12)

proses perencanaan strategi sendiri terdiri dari 5 langkah utama, seperti dijelaskan berikut:

1. Menyeleksi misi dan tujuan utama perusahaan.

2. Menganalisis lingkungan persaingan eksternal untuk mengidentifikasi peluang dan ancaman.

3. Menganalisis lingkungan kerja internal untuk mengidentifikasi kekuatan dan kelemahan organisasi/perusahaan.

4. Memilih strategi-strategi yang dibangun atas kekuatan organisasi dan mengoreksi kelemahankelemahan organisasi untuk mendapatkan keuntungan dari peluang lingkungan eksternal dan menghadapi ancaman eksternal. Strategi-strategi ini harus konsisten dengan misi dan tujuan utama perusahaan. Serta kongruen (sama dan sebangun) dan mendukung bisnis model yang berkelanjutan.

5. Implementasi strategi.

Strategi ditujukan untuk memperoleh keunggulan daya saing dan meningkatkan performa perusahaan. Semua perusahaan yang berada di dalam industri tertentu saling bersaing untuk menjadi yang terkuat dan menghasilkan keuntungan yang terbesar di dalam industri tersebut. Semua jenis perusahaan tersebut berusaha lebih unggul daripada pesaingnya atau berusaha untuk mempunyai competitive advantage atau keunggulan bersaing (Udaya, J. dkk,2013: 7). Diakui, teknologi digital (mulai dari cloud computing, digital mobility, location-based services, big data \& analytics, social media, internet of things, machine learning, hingga artificial intellegence) memiliki pengaruh yang makin krusial bagi penciptaan daya saing perusahaan
(Rudito, 2017: XXIV).

Hadirnya teknologi ini menuntut perusahaan konvensional melakukan transformasi ke arah digitalisasi atau yang biasa dikenal dengan istilah transformasi digital. Meski lekat dengan teknologi, transformasi digital tidak hanya terkait dengan masalah teknologi. Transformasi digital adalah sebuah transformasi organisasi menyeluruh yang mencakup perubahan aspek-aspek krusial lain seperti strategi, proses, SDM dan budaya hingga leadership. (Rudito, 2017:50).

Lebih dari itu, Rudito menjelaskan, transformasi digital menuntut perusahaan mengembangkan dua kemampuan yaitu kemampuan digital (digital capability) dan kemampuan kepemimpinan (leadership capability). Kemampuan yang pertama berkaitan dengan aspek the "what" of technology (kemampuan membangun dan mengembangkan teknologi digital), sedangkan yang kedua menyangkut the how of leading change (kemampuan mengarahkan dan menggerakkan perubahan).

Sedangkan kapasitas digital adalah kemampuan perusahaan dalam menerapkan teknologi digital untuk meningkatkan daya saing dengan tiga cara yaitu memperkaya pengalaman konsumen (customer experience), mentransformasi proses operasi (operational process) dan menemukan kembali model bisnis (business model). Untuk sukses menjalankan transformasi digital, perusahaan harus bisa menuntaskan sebagian atau keseluruhan dari tiga cara tersebut.

\section{METODOLOGI PENELITIAN}

\section{Pendekatan dan Strategi penelitian Kualitatif}

Penelitian ini menggunakan pendekatan penelitian kualitatif. Dalam penelitian kualitatif, periset adalah bagian integral dari data, artinya periset ikut aktif dalam menentukan jenis data yang diinginkan (Kriyantono, 2006:57). Peneliti, secara sendiri atau dengan bantuan orang 
lain merupakan alat pengumpul data utama (Moleong, 2006:9). Peneliti secara aktif berinteraksi secara pribadi. Proses pengumpulan data dapat diubah dan hal itu bergantung pada situasi. Peneliti bebas menggunakan intuisi dan dapat memutuskan bagaimana merumuskan pertanyaan atau bagaimana melakukan pengamatan. Individu yang diteliti dapat diberi kesempatan agar secara sukarela mengajukan gagasan persepsinya bahkan berpartisipasi dalam analisis data (Moleong, 2006: 32).

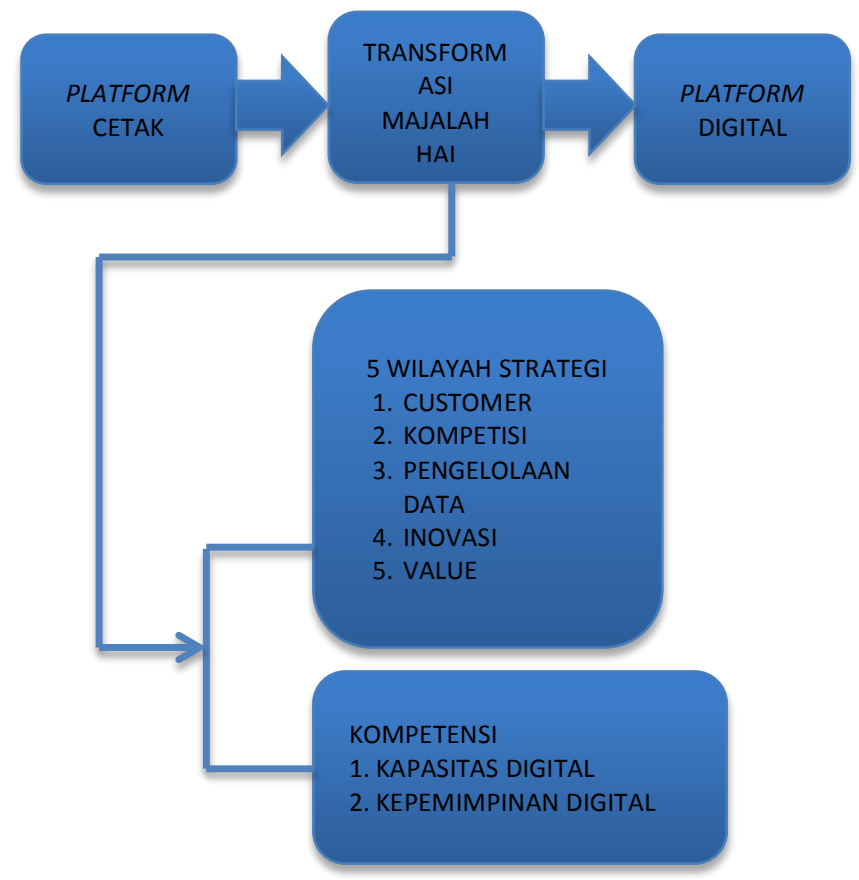

Gambar 3. Kerangka pemikiran

Eratnya hubungan peneliti dengan subjek yang diteliti memunculkan sejumlah kritik terhadap pendekatan kualitatif. Pertama, terkait objektivitas hasil penelitian karena kemungkinan munculnya bias sebagai hasil dari keterlibatan opini dan nilai-nilai yang dimiliki oleh peneliti. Karena itu, untuk meminimalisasi potensi bias, peneliti harus bersifat terbuka dan menyatakan secara jelas (eksplisit) hal-hal terkait nilai yang dipegangnya sehingga memungkinkan orang lain yang membaca hasil penelitian memiliki penilaian tersendiri atas hasi temuan penelitian. Kedua, terkait reflexivity. Pada prinsipnya hal ini terjadi karena peneliti adalah bagian dari dunia sosial yang ingin diteliti. Sehingga bagaimana ia menginterpretasi suatu fenomena akan memengaruhi pemilihan konsep, teori dan bahasa yang digunakan. Ketiga terkait relativitas data yang digunakan dalam penelitian yaitu berupa kata-kata, teks dan gambar yang diinterpretasikan oleh peneliti bukan data yang diolah secara matematis atau menggunakan statistik seperti pada penelitian kuantitatif (Denscombe, 2010:134). Dengan demikian laporan penelitian akan berisi kutipan-kutipan data untuk memberi gambaran penyajian laporan tersebut.

Selanjutnya, Penelitian kualitatif ini bersifat deskriptif yang bertujuan membuat deskripsi secara sistematis, faktual dan akurat tentang fakat-fakta dan sifat-sifat populasi atau objek tertentu (Kriyantono, 2006: 69). Metode deskriptif sangat berguna untuk melahirkan teoriteori yang bersifat tentative. Metode deskriptif-kualitatif mencari teori, bukan menguji teori; hypothesis-generating, bukan hypothesis testing dan heuristic, bukan verifikasi (Ardianto, 2010: 60).

Penelitian ini menggunakan strategi penelitian studi kasus. Penelitian studi kasus merupakan tipe pendekatan yang menelaah satu kasus secara intensif, mendalam, mendetail dan komprehensif (Ardianto, 2010: 64).

Menurut Robert K. Yin (2008:1) secara umum studi kasus merupakan strategi yang lebih cocok bila pokok pertanyaan suatu penelitian berkaitan dengan how atau why, bila peneliti hanya memiliki sedikit peluang untuk mengontrol peristiwa-peristiwa yang akan diselidiki dan bilamana fokus penelitiannya terletak pada fenomena kontemporer (masa kini) di dalam konteks kehidupan nyata.

Lebih lanjut Yin mengatakan, sebagai suatu upaya penelitian, studi kasus dapat memberi nilai tambah pada pengetahuan kita secara unik tentang fenomena individual, organisasi, sosial dan politik. Studi kasus memungkinkan 
peneliti untuk mempertahankan karakteristik holistic dan bermakna dari peristiwa-peristiwa kehidupan nyata, seperti siklus kehidupan seseorang, prosesproses organisasional dan manajerial, perubahan lingkungan sosial, hubunganhubungan internasional dan kematangan industri-industri.

\section{Teknik Pengumpulan Data}

Data merupakan hal yang sangat menentukan dalam setiap penelitian. Peneliti harus membuat perencanaan yang baik untuk melakukan kegiatan pengumpulan data karena prosedur ini akan menentukan baik tidaknya penelitian. Jika kegiatan pengumpulan data tidak disiapkan dengan baik atau terdapat kekeliruan dalam pengumpulan data maka data yang diperoleh pun tidak akan sesuai dengan permasalahan yang ingin dijawab oleh penelitian. Data yang diperoleh harus memiliki relevansi dengan masalah yang diteliti dan bersifat mutakhir (update) serta berasal dari sumber yang memiliki kredibilitas.

Bukti atau data untuk keperluan studi kasus bisa berasal dari enam sumber, yaitu dokumen, rekaman arsip, wawancara, pengamatan langsung, observasi partisipan dan perangkatperangkat fisik (Yin, 2008:103-118):

1. Dokumentasi

2. Rekaman arsip

3. Wawancara

4. Observasi langsung

5. Observasi partisipan

6. Perangkat fisik

\section{Narasumber}

Data primer dalam penelitian ini diperoleh melalui wawancara mendalam yang dilakukan terhadap sejumlah informan yang dianggap memiliki kredibilitas dan kewenangan dalam menyampaikan informasi terkait data yang dibutuhkan dalam penelitian. Untuk itu, peneliti memilih dan menentukan 4 narasumber seperti dimuat pada tabel berikut ini:
Tabel 1. Daftar Narasumber Penelitian

\begin{tabular}{lll}
\hline No & Nama & Jabatan \\
\hline 1. & Elwin Siregar & $\begin{array}{l}\text { Direktur } \\
\text { GOM }\end{array}$ \\
2. & Veronica Wulandari & $\begin{array}{l}\text { GM HR \& } \\
\text { Public Affair }\end{array}$ \\
3. & Didi Kasim Kaspi & $\begin{array}{l}\text { GM General } \\
\text { Interest media }\end{array}$ \\
\hline
\end{tabular}

\section{Elwin Siregar, Gramedia Majalah Group Director}

Dalam struktur organisasi Gramedia Majalah, Elwin Siregar menjabat sebagai direktur sejak bulan Mei 2011. Memulai karier di Gramedia Majalah sebagai jurnalis di majalah Hai sejak tahun 1988, berbagai jabatan pernah dipegangnya. Antara lain sebagai General Manager Women and Lifestyle Media, IT Media, Children Media and Digital Media Division, Editor in Chief in KaWanku, Komputeraktif, Citra, Gramedia Majalah Online, Bocil, XYKids!, Nova, and What Hi Fi Indonesia. Sebagai direktur, Elwin Siregar bertanggung jawab dalam menyusun strategi dan kebijakan perusahaan. Hal itu menjadikannya orang yang paling tepat atau narasumber kunci dalam penelitian ini.

\section{Veronica Wulandari, General Manager HR \& GA Affair Division}

Lulusan fakultas psikologi Universitas Gajah Mada ini bergabung dengan Gramedia Majalah sejak tahun 2003 sebagai Recruitment \& Selection officer. Ia sempat menangani bidang Employee Placement and Training dan menjabat sebagai Human Resource Development Manager pada tahun 2012. Sejak tahun 2013, Veronica Wulandari menempati posisi General Manager Human Resource and General Affairs Gramedia Majalah. Departemen yang dipimpinnya bertanggung jawab dalam mengelola sumber daya manusia dan komunikasi internal organisasi. Menjadikan Veronica Wulandari narasumber yang memiliki kredibilitas untuk memberikan berbagai informasi 
terkait sumber daya manusia dan strategi pengembangan sdm yang dijalankan di Gramedia Majalah.

\section{Didi Kasim Kaspi}

Bergabung bersama majalah Hai sebagai Desainer Grafis pada tahun 2000, dua tahun kemudian Didi, panggilan pria ini dipromosikan sebagai Redaktur Artistik, Hai, hingga Didi bergabung dengan Tim Desainer Group Media Pria, Kompas Gramedia Group of Magazine hingga tahun 2008. Pada 2009, Didi bergabung dengan Majalah National Geographic Indonesia, sebagai visual Editor, lalu pada 2011, Didi dipromosikan sebagai Managing Editor National Geographic Indonesia. Pada 2012, Didi dipercaya menangani Majalah National Geographic Indonesia versi Cetak dan Online, sebagai Editor in Chief. Dalam proses tranformasi digital Hai peran Didi adalah sebagai General Manager General Interest Media, kelompok yang membawahi brand dalam kategori umum termasuk Hai. Sebagai GM, Didi terlibat dalam pengambilan keputusan terkait konten editorial dan keputusan bisnis Hai.

\section{HASIL PENELITIAN DAN ANALISIS Transisi dari Cetak Ke Digital}

Proses transformasi dari platform cetak ke digital tidak terjadi secara langsung melainkan secara bertahap. Pada 14 April 2009 majalah Hai meluncurkan situs web www.hai-online.com. Tampilan situs web baru tersebut tak hanya lebih segar, tetapi juga menawarkan banyak fasilitas buat remaja. "Kita memang menyiapkan website baru Hai-Online ini untuk jadi alternatif tempat nongkrong, ngobrol, sharing karya, dan informasi. Tentunya juga bisa intip isi majalah Hai yang terbaru," kata Editor Hai-Online Teguh Andrianto seperti dikutip kompas.com (Tekno.Kompas.Com, 2009)

Jadi kemunculan Hai dalam platform digital (website) saat itu dimaksudkan untuk melengkapi dan memperkuat eksistensi platform cetak Hai.
Lebih lanjut dijelaskan, versi online ini pernah mereka keluarkan sekitar tahun 2004. Namun saat itu hanya memindahkan content yang dimiliki majalah ke website saja. "Sekitar tahun 2004 kita sudah memiliki namun hanya memindahkan isi majalah ke website saja. Hal ini menyebabkan stagnasi dalam content-nya, para pengunjung sudah membacanya di edisi cetaknya, sehingga berita yang di online saat itu tidak up to date." Selain website Pada 2011 majalah Hai juga sudah muncul dalam aplikasi untuk iPad bersama sejumlah brand lain dalam kelompok Gramedia Majalah seperti Nova, Otomotif dan Info Komputer. (dailysocial.id,2018)

Sedangkan setelah resmi menutup versi cetaknya, Hai menempati laman baru di hai.grid.id. Perpindahan ini dilakukan seiring dengan perombakan besar dalam struktur organisasi di Gramedia Majalah menyusul penutupan sejumlah brand media cetak dalam kelompok Kompas Gramedia yang kemudian melahirkan portal berita entertainment untuk mengakselerasi perkembangan mengakselerasi perkembangan 18 portal entertainment dan lifestyle yang selama ini dikelola Gramedia Majalah (Entertainment.Kompas.Com, 2017)

Keputusan untuk merambah platform digital ini dilakukan setelah menganalisis perubahan yang terjadi lingkungan bisnis perusahaan, menganalisis kekuatan, kelemahan di tubuh organisasi dan memproyeksikan peluang perusahaan di masa depan dalam menghadapi persaingan yang semakin meningkat, terutama munculnya pesaing-pesaing baru yang mengandalkan teknologi terkini. Analisis terhadap perubahan di lingkungan bisnis menunjukkan bahwa lansekap bisnis industri media telah mengalami perubahan ke arah digitalisasi sehingga Majalah Hai sebagai organisasi media yang berbasis teknologi media cetak merasa perlu memperluas kapasitasnya dan meningkatkan keunggulan daya saingnya.

Analisis lingkungan internal perusahaan Gramedia Majalah dilakukan 
untuk melihat kekuatan, kelemahan, peluang dan ancaman yang dihadapi perusahaan dalam situasi lingkungan bisnis yang berubah. Untuk menganalisis lingkungan internal digunakan pendekatan SWOT (Strength, Weakness, Opportunity, Threat). Seperti digambarkan dalam Gambar 3.

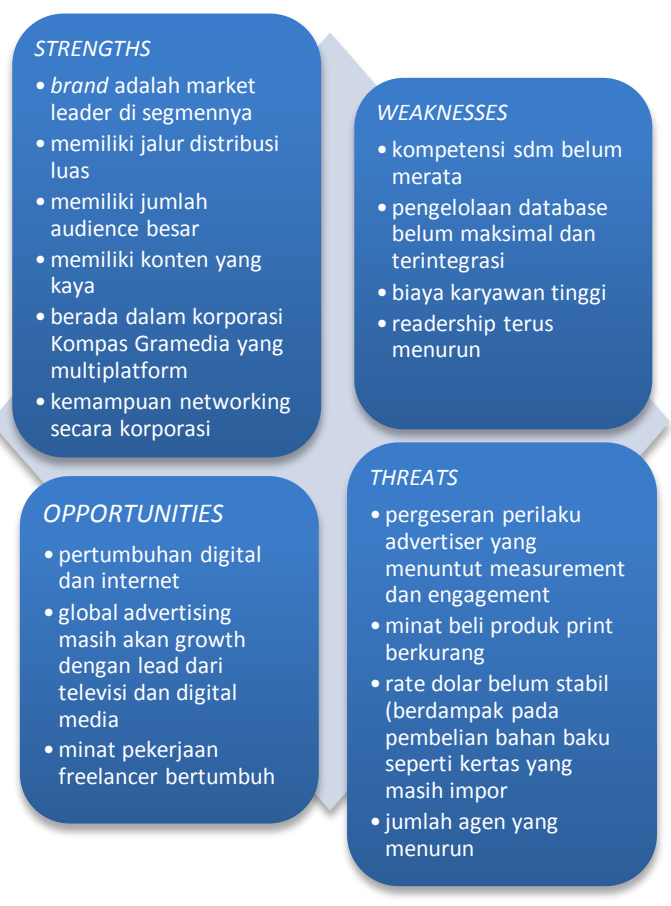

Gambar 3. Analisis SWOT Hai

Dari gambar tersebut terlihat yang
menjadi faktor pendorong untuk
melakukan transformasi digital adalah
jumlah readership yang terus menurun.
Ditambah ancaman terhadap eksistensi
platform digital yaitu perubahan perilaku
advertiser yang menuntut measurement
(pengukuran) dan engagement
(keterlibatan), penurunan minat membeli produk media cetak, rate dolar yang cenderung belum stabil dan berdampak pada meningkatnya ongkos produksi dan menurunnya jumlah agen majalah. Di sisi lain, peluang pertumbuhan digital dan internet sangat besar, diiringi potensi global advertising pada digital media. Sedangkan faktor yang mendukung optimisme untuk sukses dengan platform digital ditunjang oleh modal kekuatan yang sudah dimiliki selama ini yaitu sebagai market leader di segmen remaja pria; memiliki jumlah audience yang besar; memiliki konten yang kaya di berbagai segmen; berada dalam korporasi Kompas Gramedia yang multiplatform; Kemampuan networking secara korporasi.

Proses transformasi digital yang dilakukan oleh Hai juga bukan sekadar jawaban untuk survive menghadapi perubahan lingkungan eksternal perusahaan. Tetapi juga merupakan perwujudan dari nilai-nilai yang dijunjung perusahaan. Bagaimana Hai mampu bertahan selama lebih dari 40 tahun dilandasi oleh filosofi organisasi yang berorientasi pada kepuasaan pelanggan (customer delight) dan kemampuan untuk tetap kompetitif di tengah persaingan. Proses transformasi adalah upaya yang dilandasi oleh keyakinan bahwa bahwa di zaman modern yang serba tidak pasti yang dibutuhkan adalah keberanian menghadapi tantangan, kemampuan mengubah ancaman menjadi peluang, untuk selalu berkembang dan berorientasi pada daya saing.

"Pembaca Hai kan 15-18, itu kan artinya mereka lahir tahun 2000. Mereka digital native. Istilahnya screen generation. Kalau mau bertahan, bertahannya dimana? Kalau di print, dari kecil udah enggak kenal. Mereka liatnya Youtube. Berarti harus banyak main di video. Tapi Hai audiencenye hidup di dunia itu. Sama industrinya. Di IT ke sana. Sehingga kita kemudian membuat strategi News Brand. Tidak lagi hanya mengandalkan print tapi beberapa beberapa platform. Ada sosmed, aps, elektronik (radio, TV) lalu ada activation dan community. Masingmasing platform diharapkan memiliki kontribusi revenue." (Elwin Siregar)

Kekhawatiran Elwin akan masa depan media Hai bukan tanpa alasan. 
Kenyataan di lapangan dan riset yang dilakukan membuktikannya. Sejak tahun 2000, pihak manajemen sudah mencermati terjadinya perubahan perilaku membaca di kalangan remaja. Hal tersebut terlihat dari angka sirkulasi yang terus menurun secara signifikan.

"Sekitar tahun 2000 saya pernah diminta oleh tim sirkulasi untuk membuat presentasi, bagaimana sih bisnis media? Waktu itu saya membuat presentasi judulnya How long Can you go? Saya mengambil data dari sirkulasi semua brand yang ada di sini. Satu-satu saya bikin. Termasuk majalah Hai. Cetaknya berapa, paidnya berapa, returnya berapa. Dari semua itu menunjukkan penurunan. Waktu itu di agen ya. Dari data yang dikumpulkan enggak ada tuh yang berbeda atau aneh sendiri gitu enggak ada. Semuanya menunjukkan angka penurunan. Dari situ saya sudah melihat memang ada perubahan di minat baca. Bukan minat baca tepatnya. Tapi perilaku membaca."

Jadi manajemen memang sudah melihat bahwa terjadi perubahan perilaku membaca yang dibuktikan dari turunnya jumlah angka pembelian yang dikumpulkan melalui agen di semua produk yang dijual oleh Gramedia Majalah melalui agen penjualannya.

Dalam bisnis media cetak, ada tiga indikator untuk mengetahui bahwa sebuah produk diterima atau tidak oleh khalayak sasaran. Pertama, berapa jumlah eksemplar yang dicetak untuk suatu edisi, kedua dari jumlah cetak yang beredar di pasaran, berapa jumlah eksemplar yang berhasil terjual dan ketiga berapa jumlah eksemplar yang dikembalikan oleh agen, yang dikenal dengan istilah retur (pengembalian produk). Seperti disampaikan Elwin Siregar, ketiga indikator tersebut memperlihatkan kondisi yang menurun secara signifikan.
Tentu saja kondisi ini berdampak pada kondisi finansial Hai. Selain turunnya pemasukan dari angka penjualan, menurunnya jumlah eksemplar merupakan salah satu indikator menurunnya jumlah audience yang mengkonsumsi majalah tersebut. Hal ini sangat mempengaruhi pertimbangan klien dalam untuk menggunakan media tersebut sebagai saluran pemasaran atau promosi produknya. Padahal, seperti telah dijelaskan pada bagian kerangka teori, pemasukan terbesar majalah berasal dari perolehan iklan. Dengan kata lain, hidup dan matinya media tersebut sangat ditentukan berapa banyak perolehan yang didapat dari menjual halamannya kepada pengiklan potensial. Sehingga perubahan ini pada gilirannya berdampak terhadap perolehan iklan.

"Sejak 2012 perubahan terus berjalan. Orang sudah mulai punya social media. Klien-klien mulai bikin website, pilihan di Facebook dan seterusnya, sehingga klien atau brand owner tidak hanya (beriklan) di print tapi mulai ke mana-mana. Dan itu kelihatan di Nielsen. Trend penurunan terus berlangsung sejak 2013 hingga 2015 turun terus.” (Elwin Siregar)

Beralihnya pengiklan dari media cetak ke media digital tentu dapat dipahami karena saluran digital memiliki berbagai keunggulan yang tidak dimiliki oleh media cetak. Selain dari segi jangkauan khalayak yang tak terbatas, keterjangkauan pesan bisa diukur secara transparan. Berbeda dengan media cetak di mana pengiklan hanya berpatokan pada klaim jumlah eksemplar atau oleh organisasi media tersebut. Alhasil, majalah secara perlahan namun pasti mulai ditinggal sebagai saluran beriklan.

Untuk meningkatkan daya saing Majalah Hai di era digital, kemudian disusun strategi yang mencakup 5 wilayah strategi seperti yang dijabarkan oleh 5 
Rogers yaitu: 1. Audience; 2. Competition; 3. Data; 4. Inovasi; 5. Value.

\section{Wilayah Strategi \\ Audience}

Pada platform cetak, khalayak media dikenal dengan sebutan pembaca atau readers. Sesuai dengan sifat media konvensional yang bersifat satu arah, demikian pula halnya sifat hubungan yang menggambarkan pembaca dengan medianya. Dengan demikian, pada platform cetak, pembaca dipandang sebagai target yang disasar untuk mengkonsumsi informasi yang disajikan sekaligus menjadi khalayak sasaran pengiklan yang mengidentifikasikan customernya dengan khalayak media dimaksud. Jadi dalam hal ini media bertindak juga bertindak sebagai penghubung antara khalayak dengan produsen produk tertentu yang beriklan atau memasarkan produk atau jasa di media. Keterlibatan khalayak sangat minim baik dengan media sebagai produsen informasi maupun produsen produk atau jasa yang mengiklankan produknya di media.
Pada platform digital kastemer dipandang sebagai kumpulan orang yang secara dinamis terhubung dan berinteraksi dengan cara-cara tertentu yang mengubah hubungan mereka dengan produsen dan hubungan dengan sesama kastemer. Pada era digital konsumen meminta lebih. Mereka tak lagi bisa didikte untuk menerima konten apa saja yang disajikan media. Alih-alih mereka menjadi penentu konten apa yang diinginkan, serta memiliki keterlibatan dengan customer lainnya dalam bentuk berbagi komentar, pengalaman atau pun rekomendasi.

Pengenalan terhadap audience penting dilakukan karena pada industri media pada umumnya dan majalah khususnya karena hal tersebut menjadi faktor penentu dalam merumuskan wilayah strategi lainnya. Dari analisis isu eksternal yang dilakukan Hai, terlihat bahwa terjadi perubahan customer decision journey (proses pengambilan keputusan kastemer untuk melakukan pembelian), antara lain berupa munculnya belanja online sebagai trend baru, social media untuk akses informasi, lifestyle dan enterpreneur serta kecenderungan audiens yang semakin terfragmentasi kebutuhan dan tuntutannya.

\section{ANALISIS ISU STRATEGIS EKSTERNAL}

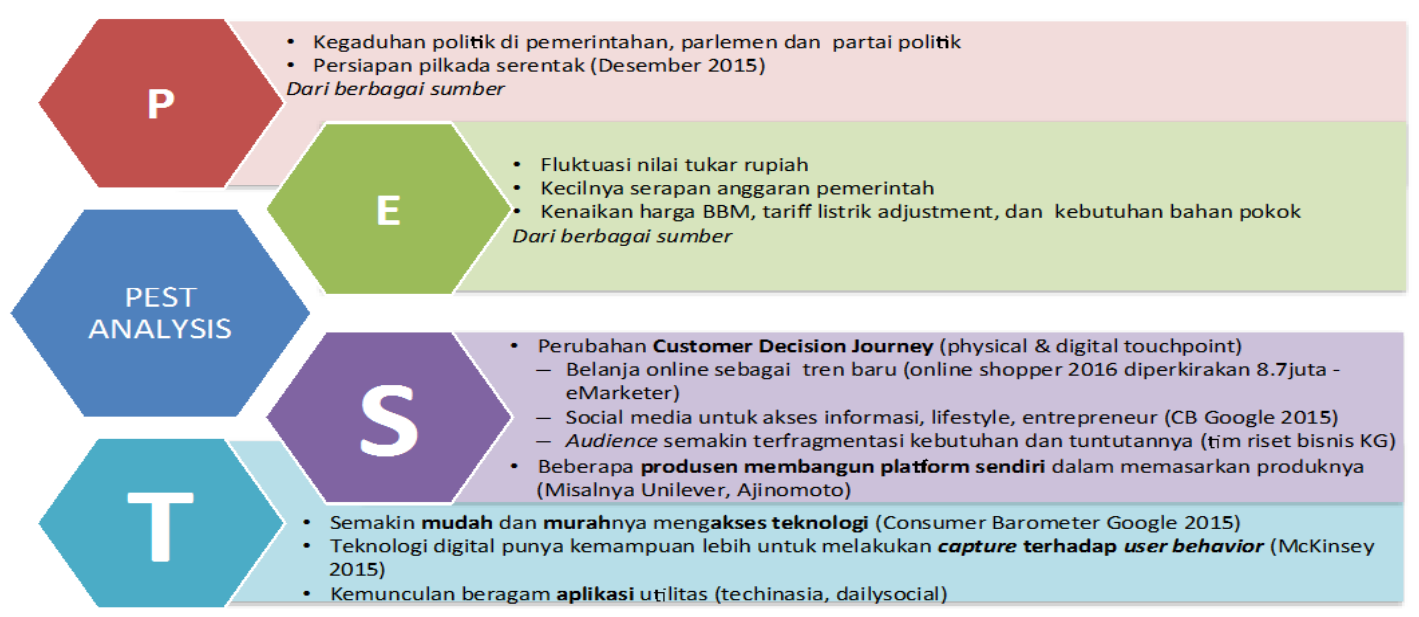

Gambar 4. Analisis Isu Eksternal

Sumber : SMO 
Selama ini menurut Elwin yang menjadi keunggulan Hai salah satunya adalah dalam hal komunitas dan memberikan wadah bagi remaja untuk tampil. Ketika 'trend' perkelahian pelajar menjangkiti anak muda di akhir 1980-an Hai menggagas sebuah acara yang melibatkan para “jagoan” sekolah. Mereka diajak bertemu untuk berkolaborasi secara positif dalam forum bertajuk Hai Informal Meeting - yang lalu berubah nama menjadi Pesta Pelajar. Pesta Pelajar mampu menjadi wadah bagi murid remaja untuk unjuk gigi dengan cara positif. Selain sebagai ajang pencarian bakat sekaligus menjadi jembatan komunikasi antarpelajar. Pada ajang Pesta Pelajar tersebut, Hai berperan sebagai fasilitator yang memberi pengarahan, mengajarkan keterampilan manajerial dan berorganisasi kepada para siswa yang terlibat dalam kepanitiaan. Sukses Pesta Pelajar kala itu lantas menjadi cikal bakal format Pentas Seni yang kerap diselenggarakan di berbagai sekolah di kota besar pada tahun 90 dan 2000'an. Beberapa ajang lainnya adalah Dream Band, Skulizm, Hai Day. Eventevent ini selain memberikan wadah untuk tampil juga memberikan peluang Hai untuk membangun audience.

Pada platform digital strategi membangun komunitas berlanjut dan diperluas dengan strategi membangun keterlibatan (engagement) dengan menciptakan 'tempat nongkrong' baru di dunia digital. Seperti disampaikan dalam artikel perpisahan majalah Hai.

"Lewat dunia digital, kita bisa terus having fun. Mau sekedar curhat boleh, nyebar info acara sekolah atau kampus nggak masalah. Promosi lagu baru band kalian juga ayok aja. Yang penting, kita nggak ngerugiin orang lain.

Intinya, lewat platform digital kita bisa ngelakuin banyak hal seru dan positif. Setuju, dong?
Terus, kenapa kami memutuskan untuk fokus di dunia digital dan nggak lagi hadir dalam bentuk fisik? Jawabannya jelas, karena kami pengin selalu hadir realtime, kapanpun kalian butuh. Hal ini, nggak bakal bisa dilakukan kalau masih ada batas halaman dan jadwal "pertemuan" tiap minggu."

Efeknya, kalau udah betah "nongkrong", siapa tau nantinya kita bisa ngulik bareng hal-hal baru. Seperti di edisi cetak terakhir Hai kali ini. Kami mau buktiin kalau majalah emang udah nggak mampu nampung begitu banyak pengalaman teman-teman kita di luar. Caranya? Dengan ngasih link di beberapa halaman menuju platform lainnya." (hai.grid.id)

Bentuk keterlibatan yang dibangun Hai meliputi 3 wilayah yaitu antara Hai dengan audience, antara audience dengan audience dan antara audience dengan pengiklan. Caranya menurut Elwin adalah adalah dengan menyajikan konten yang berpotensi shareable dan memanfaatkan semua saluran digital seperti media sosial.

\section{Kompetisi}

Pada era cetak, Hai berkompetisi dengan majalah lainnya di segmen tersebut. Salah satu yang membuat Hai sanggup bertahan sampai dengan 40 tahun karena kompetitor di segmen majalah remaja pria yang menjadi 'lahan bermain' Hai bisa dibilang tidak ada. Industri majalah di Indonesia disesaki oleh produk majalah dalam segmen wanita dan remaja perempuan. Hanya Majalah Hai yang mengklaim dirinya sebagai majalah remaja umum pria. Sehingga, yang dianggap kompetitor adalah majalah-majalah yang memiliki irisan segmen seperti majalah musik Trax, majalah otomotif dan majalah segmented semacamnya.

Di era digital, Majalah Hai menghadapi banyak pesaing tak 'tidak 
kelihatan'. Pesaing muncul dari arah tak terduga. Baik yang berasal dari industri sejenis (majalah dan media pada umumnya), industri lain yang selama ini merupakan pengiklan potensial, maupun pesaing yang sifatnya individual seperti blogger, vlogger, atau influencer. Persaingan yang terjadi tidak hanya dalam soal perebutan audience tetapi juga persaingan dalam memperebutkan kue iklan. Di era media konvesional, persaingan kue iklan biasa terjadi di antara pemain-pemain dalam industri sejenis. Namun kini para pengiklan memiliki banyak pilihan saluran media untuk memasarkan produknya dengan harga yang relatif lebih murah, berdaya jangkau lebih luas dan bisa membangun loyalitas brand tanpa bantuan media konvensional.

"Di era ini kita sedang shifting. Industri digital belum ada. Digital tidak sewangi yang dikatakan orang-orang. How they spend money on digital platform juga belum ketemu polanya. TV juga turun. Orang juga banyak bikin media digital sendiri. Menurut saya ini masih sebuah lautan yang berantakan. Kita shifting ke media baru. Coba deh cek di financial statement media digital yang tidak sebegitunya amat. Skalanya masih kecil-kecil. Kita masih sama-sama mencari bagaimana menghitung Return of Investment, misalnya. kitia shifting industri. Memang tidak nyaman. Tapi kita memang sudah terlalu lama berada di zona nyaman.” (Didi Kasim)

Menghadapi menghadapi iklim persaingan digital yang ketat dengan peta kompetisi yang berubah-ubah, Hai menerapkan strategi multichannel yaitu memanfaatkan dan memaksimalkan semua salauran digital yang ada untuk memperluas jangkauan. melalui konsep multichannel atau memaksimalkan semua saluran digital yang ada, yaitu Twitter, Facebook, YouTube, Instagram
"Nah, lewat www.hai-online.com serta akun social media kami di Twitter, Facebook, YouTube, sampai Instagram, kami bakal 'nongkrong' sama kalian lebih sering. Penginnya, sih, kita bisa punya "tongkrongan" baru yang seru di dunia digital.

Mau liat aksi band keren, kita sambungin langsung ke Facebook Live, mau liat keseruan Hai Day, langsung kami antar ke Hai YouTube Channel. Nah, pokoknya bakal bikin jadi paham deh, kalo kita itu \#needmorespace."

Persaingan yang ketat dengan peta kompetisi yang terus menerus berubah menuntut kreativitas lebih. Hal ini yang kemudian mendorong lahirnya keputusankeputusan strategis berikutnya seperti pengelolaan data inovasi.

\section{Data}

Pada platform cetak, perusahaan mengandalkan data penjualan yang dikumpulkan oleh agen untuk melahirkan keputusan-keputusan yang terkait konten maupun strategi bisnis.Untuk membaca selera pasar biasanya dilakukan survei pelanggan yang dilakukan oleh lembaga survei internal. Selain itu, pengambil keputusan (dalam hal konten, keputusan tertinggi berada di tangan pimpinan redaksi) dituntut untuk memiliki kepekaan atau penciuman yang tajam terhadap isuisu yang akan menghasilkan respon positif dari khalayak. Feedback dari khalayak bisa diperoleh, namun tidak bersifat langsung dan segera.

Pada platform digital respons pasar bersifat transparan dan terukur. Seperti disebutkan sebagai 'ancaman' pada analisis PEST di atas (tabel 4.2), Teknologi digital memiliki kemampuan lebih untuk melakukan capture terhadap user behavior. Contohnya apa saja konten yang akses, siapa saja yang mengakses 
konten tersebut, berapa lama waktu yang dihabiskan untuk menelusuri kontenkonten, bagaimana tingkat kepuasan pengguna dan berbagai data yang bersifat detail.

"Enaknya, semua pekerjaan kita sekarang terukur. KPI (Key Performance Indicator) kita sangat terukur. Di cetak kita nggak tau, siapa yang benar-benar baca majalah kita. Yang kita tau orang yang beli majalah. Dan itupun masih sangat abu-abu datanya. Bisa saja 1 majalah dibaca 10 orang. Di media digital kita tau, orang yang baca doang, orang yang ngeklik doang. Dulu ketika kita diminta membuat artikel kita nggak punya gambaran apa-apa. Nggak tau apakah artikel yang kita buat berdampak. Hanya bisa berharap sirkulasi kerjanya benar, yang penting kita bikin artikel dan pastinya layak muat. Kita nggak mikirin strateginya harus diapain supaya dibaca banyak orang, harus diapa-apain, yang penting majalahnya terbit, ada di pasaran. Dulu print sepertinya eksklusif. Kita mengutamakan konten di print, digital dapat sisanya. Sekarang terbalik, print itu additional platform. Jadi kita memang perlu membuat content strategy." (Didi Kasim)

Seperti dijelaskan Didi Kasim strategi dalam hal pengelolaan data yang dilakukan dimulai dari membuat strategi konten dengan memanfaatkan data analytic seperti Google Analytic. Dari situ bisa diperoleh pola user behavior hingga detail yang diinginkan. Data itu kemudiana dianalisis dan digunakan untuk membuat kebijakan terkait konten dan aspek bisnis. Maksimalisasi data ini berlaku untuk semua platform digital yang dimiliki Hai. Optimalisasi Customer Relationship Management (CRM) melalui pengembangan database customer yang lebih komprehensif baik secara kuantitas maupun kualitas dan pengelolaan komunitas yang lebih intensif.

\section{Inovasi}

Transformasi dari platform cetak ke platform digital pada hakikatnya adalah sebuah perubahan mendasar yang berdampak ke segala aspek. Untuk survive menghadapi perubahan yang terjadi, semua pihak terkait harus bisa beradaptasi dan memiliki mindset untuk selalu melakukan inovasi. Jakob Oetama, founder Kompas Gramedia mengatakan perubahan adalah hakikat eksistensi media. Perubahan besar tidak saja menyangkut keserentakan dan kecepatan penyampaian informasi, tetapi juga peningkatan mutu dan pencarian kiat-kiat baru (Sularto, 2015:245). Tranformasi digital diyakini sebagai kiat yang harus ditempuh untuk mempertahankan eksistensi majalah Hai.

Menurut Elwin, bila berbicara soal produk jurnalistik, antara platform cetak dan digital pada dasarnya sama. Ada produk jurnalistik yang dikatakan baik ada yang tidak. Perbedaannya adalah dalam hal penyajian. Pada platform digital, kreativitas sangat dimungkinkan karena teknologinya terus berkembang sehingga inovasi yang dilakukan dalam konten lebih ke arah penyajian dan pemanfaatan fiturfitur atau teknologi baru.

"Sebenarnya hukum digital sama saja. Jurnalistik itu tidak membedakan platform. Yang membedakan produk jurnalistik adalah bagus atau tidak bagus. Caranya aja kalau di print paling hanya bisa sampai di infografik. Tapi kalau digital karena platformnya

memungkinkan, kita bisa pakai video, animasi, audio, macam-macam.

Desainnya juga bisa variatif. Persoalan di digital itu, mau se-kreatif apa sih? Ketika itu disukai dan dishare itu membangkitkan kredibilitas." (Elwin Siregar)

Selain melakukan pembaruan dari segi konten, inovasi juga dilakukan untuk mempertahankan pemasukan dari segi 
iklan yang menjadi penopang hidup Hai. Salah satunya melalui bentuk content marketing.

"Bergerak di digital itu bukan cuma soal content. Kalau digital kan revenue streamnya cuma iklan, tidak seperti di print yang juga punya pemasukan dari sirkulasi. Dan iklan diperoleh melalui data. Penguasaan sosial media saja tidak lantas menjadikan bisa menjadi social media strategic. Sehingga dia juga harus punya kemampuan analitis. Dia harus bisa mengulik data. Mesti tau SEO. Banyak orang yang sulit berubah. Tapi ya tantangannya memang harus begitu. Digital native bisa dibilang sebagai advantage karena keakraban mereka dengan gadget. Tapi kalau mengenai analitis, mirip-mirip lah. Kalau digital immigrant yang lebih ngotot dan ngulik dia bisa lebih jago. Masalahnya mau atau nggak, karena di luar kebiasaan mereka. “

"Saya kasih tau bahwa nanti yang namanya iklan display itu nggak ada lagi. Bayangin orang udah bosen melihat layar kecil dan dipenuhi iklan dan itu sangat mengganggu. Dan itu sudah disadari oleh banyak orang sehingga muncullah yang namanya ad-blocker dan semacamnya. Sehingga kita mesti ngapain dong untuk mengantisipasinya? Salah satunya dengan membuat content marketing. Apa itu? Yaitu bagaimana semua orang yang masuk ke situ merasakan manfaatnya. Bukan merasa dijual. Dalam istilah kerennya inbound. Jadi orang datang malahan. Contohnya seperti Krating Daeng. Kita exercise, key words-nya apa, insightnya apa. Content marketing itu bukan untuk sales tapi untuk membuat orang ingin. Sharing ini dilakukan di kelas, dengan presentasi, flipchart, $d s b$. Lalu dimonitor pelaksanaannya, diuji, lalu dijual. “ Elwin Siregar.

Bisa disimpulkan bahwa dalam proses tranformasi digital, inovasi merupakan kunci keberhasilan. Sehingga menurut Elwin, setiap karyawan harus memiliki mindset untuk kreatif dalam menciptakan ide-ide baru karena perubahan berlangsung sangat cepat dan terus menerus.

\section{Value}

Value atau nilai, menurut Rogers merupakan domain final transformasi digital, yaitu bagaimana value yang dimiliki oleh perusahaan disampaikan kepada kastemer.

Strategi Hai dalam menyampaikan value adalah bagaimana menciptakan voice. Yang dimaksud dengan menjadi voice adalah sebagai media yang bergerak dalam bidang informasi, Hai harus selalu menyampaikan gagasan yang penting, menarik dan dibutuhkan oleh masyarakat.

"Saya selalu bilang, jadilah voice bukan noise. Harus ada gagasan yang ingin disampaikan. Karena jualan kita sebagai media ya itu. Kalau di dunia teknikal yang penting adalah 'how', kalau di dunia jurnalistik yang penting adalah 'why' sampai kita menemukan hal yang berhubungan dengan sisi kemanusiaan. Dan itu basic, apa pun platformnya. “ (Elwin Siregar)

Menurut Elwin, value yang dimiliki perusahaan dan diwarisi dari para founder adalah integritas dalam berbisnis.

"Kita pada ultah ke 50 menyatakan ingin bertahan 50 tahun ke depan. Apa syaratnya? Bukan teknologi. Tapi integritas. Integritas itu rumusnya cuma satu, perkataan 
dan perbuatan sama. Itu yang menumbuhkan krebilitas.

Trustworthy. Kalau kita sudah kehilangan itu, mau teknologi secanggih apa pun pasti kita kalah. Kita memakai konsultan untuk mencari rahasia sukses KG itu apa, jawabannya integritas.” (Elwin Siregar)

" Pertama, kekuatan brand, itu yang tidak dikalahkan. Kita juga percaya bahwa voice itu sama dengan revenue, sehingga jangan ngejar revenuenya dulu, kejar voicenya dulu. Mereka begitu terpapar oleh informasi kekuatan brand menentukan.” (Didi Kasim)

\section{Pengembangan Kemampuan Kapasitas Digital (Digital Capability)}

Perubahan yang sangat cepat dari era cetak ke digital memaksa karyawan untuk bisa beradaptasi dan ini menimbulkan berbagai persoalan yang kompleks di tubuh organisasi. Founder Kompas Gramedia Jakob Oetama dalam berbagai kesempatan menekankan perlunya pengembangan kompetensi atau competence building, yaitu selalu membuka diri untuk mengembangkan diri dan kemampuan bekerja secara profesional, meningkatkan keterampilan/kompetensi agar selalu dapat memutakhirkan (up to date) kemampuan kerja sesuai tuntutan pertumbuhan teknologi informasi, kreatif dan berwawasan, visioner, pengembangan leadership untuk peremajaan pimpinan dan kaderisasi (Sularto, 2015:169).

Transformasi dari perusahaan media cetak ke digital mensyaratkan penguasaan akan teknologi baru yaitu teknologi digital. Agar tetap kompetitif dan menghasilkan produk dan prosesproses baru, peningkatan kompetensi sumber daya manusia harus dilakukan terus menerus. Proses yang dilakukan dalam rangka mempersiapkan SDM Hai yang kompeten di era digital dimulai dari rekrutmen, peningkatan knowledge dan pengembangan skill karyawan secara berkesinambungan sesuai dengan kebutuhan.

“Dimulai dari rekrutmen ya, pasti menyesuikan dengan posisinya apa, sourcingnya juga banyak banget, mau dari head hunter, situs online atau datang ke kampus. Jadi ketika merekrut sudah kita sesuaikan dengan kebutuhan. Misalnya ada tes membuat program dari brief yang diberikan. Dan terkait situasi perusahaan saat ini, kita tanya juga soal kemampuan digitalnya. Mulai dari yang paling sederhana apakah dia aktif di social media, bagaimana mereka mengelola social medianya, bahkan kita mengintip social medianya. Seberapa aktif. Itu paling tidak menandakan dia catch up atau tidak dengan dunia digital. Kita juga selalu melibatkan user dalam merekrut. Setelah direkrut ada orientasi. Di bahan orientasi itu kita menyebutkan bahwa perusahaan ini growing ke arah digital. Setelah itu mereka langsung diterjunkan dalam pekerjaan. Di sini kita mengharapkan peran manajernya untuk membantu mengembangkan kompetensinya. Dari situ bila ada permintaan akan pelatihan-pelatihan khusus kita akan follow up. Misalnya pelatihan mengenai infografis, indepth reporting dan sebagainya. “ (Veronica)

Sebelum terjun langsung, karyawan baru dibekali pelatihan agar mereka lebih mudah memahami seluk beluk berkarier dan budaya yang ada di perusahaan. Dalam pelaksanaannya, karyawan baru dilatih untuk terjun langsung dalam pekerjaan dengan oleh karyawan senior agar lebih cepat beradaptasi. Perusahaan juga mengadakan training untuk karyawan 
setiap bulan atau dalam kurun waktu tertentu. Tujuannya untuk mendapatkan SDM profesional dan juga ahli dalam bidang pekerjaan yang dikerjakan. Tenaga profesional, ahli dan terdidik diharapkan bisa membawa perusahaan menuju kemajuan dan perkembangan yang pesat. Serangkaian program disiapkan dalam rangka pengembangan kompetensi di bidang digital.

Selain program yang dipersiapkan oleh diklat sebagai kebutuhan dasar karyawan secara umum juga dibuat pendidikan atau pelatihan dibuat berdasarkan kebutuhan yang diusulkan oleh unit. Misalnya, pelatihan SEO (Search Engine Optimization), Digital Sales Advertising, Basic Video for Journalist dan lain-lain. Program pelatihan bisa bersifat formal dan informal, berupa pelatihan-pelatihan dan pengembangan skill dengan mendatangkan narasumber dari internal dan eksternal perusahaan atau menerapkan learning by doing system berupa job/project assignment.

\section{Kapabilitas Kepemimpinan (Leadership Capability)}

Untuk melaksanakan perubahan diperlukan orang-orang yang yakin bahwa perubahan akan mengarah ke situasi dan kondisi yang lebih baik. Karena itu perlu dibentuk kelompok yang bisa menunjukkan antusiasme, komitmen, kepercayaan bahwa dengan perubahan yang akan dilakukan akan mendatangkan hasil yang lebih baik. Untuk meningkatkan motivasi karyawan dan membangkitkan kesadaran ke arah perubahan diperlukan contoh nyata yang bisa menginspirasi sehingga bisa diteladani dan memberikan rangsangan untuk melahirkan karya-karya inovatif yang sejalan dengan strategi perubahan. Di sinilah pentingnya keberadaan pimpinan yang tidak hanya memiliki kemampuan memotivasi, tapi juga bisa menjadi motor penggerak organisasi. Dimulai dari pimpinan tertinggi organisasi (dalam hal ini Direktur Utama) hingga supervisor.

Dalam proses transformasi menuju era digital, menurut Elwin Siregar, di tahap awal karyawan banyak dirangsang untuk melahirkan inisiatif-inisiatif digital yang sifatnya parsial, yang kemudian dijadikan semacam pilot project dan contoh yang bisa diduplikasi.

"Kita banyak melakukan in-house training oleh orang-orang dalam yang memang berkecimpung di digital. Termasuk saya (Direktur Utama). Jadi kesimpulannya dibikin pilot project di mana direktur turun langsung dengan tim inti. Kalau ini berhasil kemudian menjadi contoh yang ditularkan.” (Elwin Siregar)

Menyadari pentingnya peran pimpinan dalam membangun mindset digital, secara rutin juga dilakukan pengembangan skill dan knowledge di lini pimpinan. Seorang pimpinan di era digital dituntut menguasai hal-hal yang berkaitan dengan pengelolaan sumber daya, produksi konten dan aspek bisnis. Misalnya kemampuan desk management, content management dan creative content management. Salah satu contoh pelatihan yang diberikan antara lain bisa dilihat dari tabel 2. 
Tabel 2.Program Peningkatan Kompetensi Manajerial

\begin{tabular}{|c|c|c|}
\hline Modul & Kompetensi & Objektif \\
\hline $\begin{array}{l}\text { Desk } \\
\text { Management }\end{array}$ & $\begin{array}{l}\text { Kompetensi mengelola } \\
\text { organisasi/sumber daya manusia } \\
\text { dengan banyak platform. }\end{array}$ & $\begin{array}{l}\text { 1. Mampu mengelola sumber daya } \\
\text { manusia dengan banyak } \\
\text { platform. } \\
\text { 2. Membuat mekanisme } \\
\text { redaksional dengan mengelola } \\
\text { kemampuan MMM. }\end{array}$ \\
\hline $\begin{array}{l}\text { Content } \\
\text { Management }\end{array}$ & $\begin{array}{l}\text { Kompetensi mengelola } \\
\text { archieve/pangkalan data konten yang } \\
\text { mudah diakses dan alihrupa. } \\
\text { Kompentensi memilah dan } \\
\text { mengategorikan jenis-jenis isi/konten } \\
\text { yang dimiliki dengan standar tertentu } \\
\text { (data konten yang terpadu). }\end{array}$ & $\begin{array}{l}\text { 1. Mengelola archive/pangkalan } \\
\text { data konten yang mudah diakses } \\
\text { dan alihrupa. } \\
\text { 2. Memilah dan mengkategorikan } \\
\text { jenis-jenis isi/konten yang } \\
\text { dimiliki dengan standar tertentu } \\
\text { (data konten yang terpadu) }\end{array}$ \\
\hline $\begin{array}{l}\text { Create } \\
\text { Creative } \\
\text { Content }\end{array}$ & $\begin{array}{l}\text { Kompetensi membuat ide kampanye } \\
\text { yang kreatif yang bisa dilakukan di } \\
\text { online maupun offline. } \\
\text { Kompetensi berpikir kreatif melihat } \\
\text { peluang bisnis dari konten yang } \\
\text { dimiliki. }\end{array}$ & $\begin{array}{l}\text { 1. Mampu membuat ide kampanye } \\
\text { yang bisa menghasilkan gerakan } \\
\text { yang bisa hasilkan revenue. } \\
\text { 2. Mampu berpikir kreatif melihat } \\
\text { peluang bisnis dari konten yang } \\
\text { dimiliki. }\end{array}$ \\
\hline
\end{tabular}

\section{KESIMPULAN}

1. Transformasi digital merupakan upaya Hai untuk tetap memiliki daya saing di tengah perubahan mendasar yang terjadi dalam industri media yang disebabkan oleh munculnya internet dan perkembangan teknologi komunikasi dan informasi.

2. Proses transformasi tidak berjalan secara langsung dalam satu momentum tetapi melalui tahapan-tahapan yang bersifat evolutif, mulai dari langkah konvergensi di mana Hai dalam platform cetak hidup berdampingan dengan platform digital lain (multiplatform) dengan tujuan mempertahankan eksistensi platform cetak yang sudah ada sejak tahun 1977.

3. Langkah konvergensi tidak berhasil mempertahankan eksistensi platform cetak Hai sehingga langkah transformasi total diambil untuk mempertahankan eksistensi brand Hai.
4. Untuk meningkatkan daya saing brand, Hai dalam platform digital, strategi yang dijalankan meliputi 5 wilayah yaitu strategi audience, kompetisi, data, inovasi dan value perusahaan. Serta meningkatkan kapasitas digital dan kapasitas kepemimpinan.

\section{DAFTAR PUSTAKA}

1. Berger, L. and Dorothy, Best Practices in Talent Management, Terjemahan, Jakarta: Penerbit PP, 2007.

2. Biagi, S., Media Impact, An Introduction to Mass Media, $10^{\text {th }}$ ed. Boston: Wardsworth, 2012.

3. Bungin, B., Metode Penelitian Kualitatif, Jakarta: Rajawali Pers, 2008.

4. Denscombe, M., Ground Rules for Social Research, London: McGrawHill, 2010. 
5. Dominick, Joseph R., The Dynamics of Mass Communication, Media in Transition, New York: McGraw-Hill, 2011.

6. Fiddler, R., Mediamorphosis, Understanding New Media, London: Pine Forge Press, 1997.

7. Kasali, R., Disruption, Jakarta: PT Gramedia Pustaka Utama, 2017.

8. Kriyantono, R., Teknis Praktis Riset Komunikasi. Jakarta: Kencana, 2012.

9. Moleong, L.J., Metodologi Penelitian Kualitatif, Bandung: PT Remaja Rosdakarya, 2006.

10. Rogers, David L., The Digital Transformation Playbook, New York: Columbia University Press, 2017.

11. Rudito, Prinyantono, Digital Mastery, Membangun Kepemimpinan Digital Untuk Memenangkan Era Disrupsi. Jakarta: PT Gramedia Pustaka Utama, 2017.

12. Straubhaar, J. et al, Media Now: Understanding Media, Culture and Technology. $\quad 7^{\text {th }}$ ed. Cengage Learning, 2012.

13. Sularto, S., Syukur Tiada Akhir, Jejak Langkah Jakob Oetama, Jakarta: Penerbit Buku Kompas, 2015.

14. Wimmer, R.D. and Dominick, J.R., Mass Media Research, An Introduction. $\quad 9^{\text {th }} \quad$ ed., Boston: Wardsworth, 2011.

15. Yin, R.K., Studi Kasus, Desain dan Metode. Jakarta: Rajawali Pers, 2008.

16. Belajar Dari Kegagalan Transformasi Digital Time, https://tirto.id/belajardari-kegagalan-transformasi-digitaltime-cEPj,

17. Edisi Reguler Majalah Hai Terakhir Terbit Hari ini, https://kumparan.com/@kumparanne ws/edisi-reguler-majalah-hai-terakhirterbit-hari-ini

18. Sudah Siap Untuk Evolusi Majalah Dengan Media Digital?, https://dailysocial.id/post/sudah-siapuntuk-evolusi-majalah-dengan-mediadigital).
19. (https://entertainment.kompas.com/rea d/2017/02/27/154658810/kompas.gra media.luncurkan.portal.entertainment. grid.id)

20. tekno.kompas.com,2009/04/14/20441 448/hai.online.diluncurkan.situsnya.ka um.remaja. 